\title{
The Seroprevalence of Toxoplasma gondii in Cats at the House of Maternal Women with Toxoplasmosis in Badung, Indonesia
}

\author{
Made Subrata $^{1 *}$, Nyoman Mantik Astawa ${ }^{2}$, Nyoman Tigeh Suryadi ${ }^{1}$, Sang Gede Purnama ${ }^{1}$, Kadek Karang Agustina ${ }^{3}$, \\ Ngakan Putu Anom Harjana ${ }^{4}$, Made Damriyasa ${ }^{5}$
}

\begin{abstract}
1Department of Public Health and Preventive Medicine, Faculty of Medicine, Udayana University, Denpasar, Indonesia, ${ }^{2}$ Department of Immunology, Faculty of Veterinary Medicine, Udayana University, Denpasar, Indonesia, ${ }^{3}$ Department of Veterinary Public Health, Faculty of Veterinary Medicine, Udayana University, Denpasar, Indonesia, ${ }^{4}$ Center for Public Health Innovation, Faculty of Medicine, Udayana University, Denpasar, Indonesia, ${ }^{5}$ Department of Clinical Pathology, Faculty of Veterinary Medicine, Udayana University, Denpasar, Indonesia
\end{abstract}

\begin{abstract}
Toxoplasmosis is a zoonotic disease caused by infection with the parasite called Toxoplasma gondii (T. gondii). The health and social impacts of the infection are enormous, including miscarriage, hydrocephalus, blindness, and mental retardation. The occurrence of toxoplasmosis in maternal women cannot be separated from cats around their houses. This study aimed to determine the seroprevalence of the parasite in cats found in the human carriers residences and identify the risk factors of toxoplasmosis in maternal women in Badung District, Bali Province, Indonesia. A total of 80 cat serum samples were obtained from two residential groups, 40 from the housing where the maternal women were infected and another 40 from where there were no identified sufferers of the disease. All the samples were examined using the enzyme-linked immunosorbent assay (ELISA) method to detect the presence of antibodies T. gondii in feral cat serum. The results showed that $47.5 \%$ of the examined subjects had the said antibodies. As much as $65 \%$ came from housing with cases of toxoplasmosis in maternal mothers, and $30 \%$ came from residences with none. The presence of feral cats is a major risk factor for the transmission of $T$. gondii to humans.
\end{abstract}

Keywords: cats, maternal women, risk factor, Toxoplasma gondii, toxoplasmosis

\section{Introduction}

Human toxoplasmosis is an emerging disease in both developed and developing countries with a varying prevalence. ${ }^{1-5}$ In Indonesia, this disease has been reported in various regions with seroprevalences ranging from $3.1 \%$ to $64 \% .{ }^{6-12}$ In Bali, Sukaryawati, ${ }^{13}$ reported a $41.8 \%$ of seroprevalence in Mengwi Subdistrict, Badung District, and a recent study found a rate of $10.9 \%$ in pregnant women. ${ }^{10}$ The previous study on toxoplasmosis among blood donors in Bali showed a seroprevalence of $35.9 \%$, while among the women blood donors were about $63.9 \%$. Furthermore, the seroprevalence of toxoplasmosis in blood donors in Badung District was 29.2\%; in Tabanan District, 38.6\%; in Gianyar District, 25.0\%; while in Denpasar City, Klungkung City, and Bangli District were $41.1 \%, 25.0 \%$, and $8.31 \%$, respectively. In each district of Bali Province, the seroprevalence of toxoplasmosis among women was reported: Badung District, 33.3\%; Tabanan District, 66.5\%; Gianyar District, $82.5 \%$; while in Denpasar City, Klungkung City, and Bangli District was $71.1 \%, 81.5 \%$, and $16.7 \%$, respectively. ${ }^{14}$ Another study determined the seropreva-

Correspondence*: Made Subrata, Department of Public Health and Preventive Medicine, Faculty of Medicine, Udayana University, Denpasar, Bali 80225 , Indonesia, E-mail: madesubrataunud@gmail.com, Phone: +62 82339449379 lence of human toxoplasmosis in the Gianyar District to be $56.7 \% .{ }^{15}$ In Bali Province, the seroprevalence for toxoplasma in animals, was also reported to be $30 \%$ in cats, ${ }^{16} 5.26 \%$ in pigs, ${ }^{17}$ and $24.8 \%$ in local chickens. ${ }^{18}$

Several epidemiological studies indicated that the presence of a cat in residence or premises increases the risk of $T$. gondii infection, especially in pregnant women. ${ }^{19-22}$ The presence of cats will pollute the surrounding environment with feces containing oocysts of the parasite. ${ }^{23}$ As reported before, the areas where there are many of the aforementioned animals roaming in the streets, markets, and public places are contaminated by the oocysts. ${ }^{24,25}$ In addition to cats which are widely highlighted as a risk factor for toxoplasmosis, eating habits increase the risk of infection with $T$. gondii in humans. ${ }^{26}$ In Europe, for instance, more infections occur as a result of consuming meat and its processed products that have not been completely cooked, ${ }^{27}$; while in Brazil, most of the infections are due to ingestion of oocysts that contaminate drinking water or vegetables. ${ }^{28,29}$ Similar findings are also reported in several developing countries. ${ }^{30}$ In Indonesia, including Bali Province, it has been

Received : April 19, 2021

Accepted : October 18, 2021

Published: November 29, 2021 
reported that eating habits, such as the consumption of lawar, a kind of food made from raw meat mixed with some vegetables and undercooked satay, determine the occurrence of these parasitic infections. $6,10,11,31,32$

The concept of one health/eco-health focuses on three main aspects in epidemiology related to toxoplasmosis, ${ }^{11}$ namely; the humans, the animals that serve as definitive hosts (such as cats), and other warm-blooded organisms that serve as intermediate hosts, as well as the environment contaminated by infective oocysts from $T$. gondii. Extant studies on the epidemiology of toxoplasmosis have only focused on one aspect. However, this study focused on three; the socio-demography of maternal women, the presence of cats as a source of infection, and the environment contaminated by the feces containing $T$. gondii oocysts. ${ }^{16}$ This type of epidemiological study, especially in maternal women, which focuses on the three aforementioned aspects, has never been carried out. In addition, studies conducted on toxoplasmosis thus far in this category of individuals and its relationship with the presence of cats as a source of transmission have never been investigated on the status of the associated infection by serological, coproscopic, and molecular tests.

\section{Method}

This study used a case-control approach while the maternal women checked their pregnancy at a clinic or laboratory in Denpasar City, Bali Province. All the positive maternal women recorded in the laboratory were used as a sampling frame, then they were selected using a simple random sampling. Those that were randomly selected as samples were divided into two groups; those that were positive for toxoplasmosis serologically (cases) and those that were negative (control). The control group was selected from the nearest neighbors of the selected sample cases. In addition, a study was carried out on cats at the home or premises of the selected maternal women. All the cats were trapped and maintained in a cage for the obtainment of samples. The number of samples was calculated by the Formula 1.33

FBy assuming a type I error $(\mathrm{Z} \alpha)$ of $5 \%$ and a type II (ZB) error of $20 \%$, the proportion of toxoplasmosis cases in Mengwi Subdistrict, Badung District, in 2011 was about $78 \%, 13$ and the proportion of toxoplasmosis among the control group was $50 \%$; the magnitude of the discordance or discrepancy $(\pi)$ was 0.38 , and the minimum sample size for each group was 40 . Therefore, the sample size of both cases and controls was 80 .

$$
N 1=N 2=\frac{(\mathrm{Z} \alpha+\mathrm{Z} \beta)^{2} \pi}{(\mathrm{P} 1-\mathrm{P} 2)^{2} \pi}=\frac{(1.96+0.84)^{2}}{(0.78-0.50)^{2}}=0.38=38 \text { samples }
$$

Formula 1. Estimate of Sample Size
The required data for the samples were obtained using a structured questionnaire. Before the examination, each of the subjects had approved their participation by signing informed consent. A total of 80 blood and fecal samples from cats were examined. Whole blood samples of $3 \mathrm{~mL}$ each were obtained from the cephalic vein, allowed to clot within sixty minutes, and separated by centrifugation; the serum was stored at freezing temperatures before being examined. Meanwhile, fecal samples were collected when the cats defecated in the cage. Each cage was cleaned and disinfected before being used for keeping the cat.

The feces and blood serum examination were carried out at the Center for Animal Disease (CSAD) laboratory, Faculty of Veterinary Medicine, Udayana University, and at the Denpasar Veterinary Investigation Center's laboratory of the Ministry of Health Agriculture of the Republic of Indonesia. Fecal samples were examined by using concentration flotation techniques to investigate the oocysts of the parasite. ${ }^{16}$ The ELISA test was conducted on the serum samples. The presence of specific gamma immunoglobulin ( $\operatorname{IgG}$ ) antibodies against $T$. gondii was determined separately by the use of indirect ELISA tests (Human-GmbH, Wiesbaden, Germany [Ger]). 34

The statistics were conducted by calculating the odds ratio $(\mathrm{OR})$ value of each examined risk factor, and by bivariate analysis using the Chi-square test $\left(\chi^{2}\right)$ to evaluate the significance of the association between the toxoplasmosis incidents on maternal women and the risk factor to obtain the $\chi^{2}, 95 \%$ confidence interval $(\mathrm{CI})$, and OR values. The statistically significant risk factors were related to the toxoplasmosis incidents on the maternal women ( $p$-value $<0.25$ ), followed by the multivariate analysis using the logistic regression test to obtain the OR and $p$-value $<0.05$ values, as well as the final model of the regression. The discovered molecule-based data were used to strengthen the result of the microscopic test to ensure that the oocyst found belonged to the $T$. gondii. All the statistical analysis was conducted with the Stata version 12.1 software.

\section{Results}

Table 1 shows the proportion and seroprevalence of T. gondii in cats living with maternal mothers in Bali Province. The authors found that $17.5 \%$ of cats were infected by $T$. gondii; $30 \%$ were from housing with cases

Table 1. The Proportion of $T$. gondii in Cats $(n=80)$

\begin{tabular}{lcccc}
\hline & \multicolumn{2}{c}{ Positive } & \multicolumn{2}{c}{ Negative } \\
\cline { 2 - 5 } Description & $\mathbf{n}$ & $\%$ & n & $\%$ \\
\hline Proportion (oocysts) & 14 & 17.5 & 66 & 82.5 \\
Seroprevalence & 38 & 47.5 & 42 & 52.5 \\
\hline
\end{tabular}


of toxoplasmosis in maternal mothers, and $5 \%$ were from residences with none. While the seroprevalence of $T$. gondii in cats was found to be $47 \%$, out of which $65 \%$ occurred in the case study area and $35 \%$ in the control area. In Figure 1, it was found that the oocysts of $T$. gondii were in two forms, e.g., sporulated and un-sporulated oocysts.

Table 2 shows the sociodemographic characteristics of the respondents. In the case group, most of them $(60.0 \%)$ were over 31 years old. While in control, most of them $(60.0 \%)$ were below that age. When considered based on the level of education, most $(50.0 \%)$ of the respondents in the case group attained high school, while most of the respondents $(52.5 \%)$ in the control group went to college. From the occupational point of view, most of them in the case group (35.0\%) and the control $(32.5 \%)$ were housewives. When observed from the history of miscarriage, most of the respondents in the case group $(80.0 \%)$ admitted having had one, and most of the control $(82.5 \%)$ claimed to have had none. From the status of antenatal care, most of them $(72.5 \%)$ in the case group were examined by a doctor, while in the control group, most $(62.5 \%)$ of them also received a similar level of care in their pregnancy.

Table 3 shows the behaviors and habits at risk of toxoplasma infection in maternal cases and control groups. The result indicated that out of 80 maternal women studied, $52.5 \%$ had frequent contact with the ground in their daily activities. In contrast, the remaining $47.5 \%$ stated that they never or rarely had such contact. Information about water sources used for daily activities

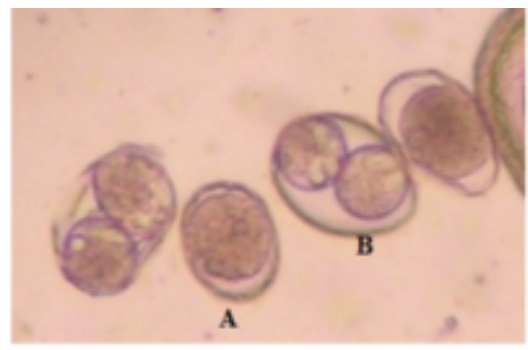

Notes:

A: Un-sporulated Oocysts of T. gondii; B: Sporulated Oocysts of $T$. gondii

Figure 1. The Oocysts Forms Identified from Feral Cats' Feces in the Bali Area

Table 2. Sociodemographic Characteristics

\begin{tabular}{llrrr}
\hline Variable & Category & Case n (\%) & Control n (\%) & Total n (\%) \\
\hline \multirow{2}{*}{ Age } & Under 31 years of age & 40 & 60 & 50 \\
Level of education & Over 31 years of age & 60 & 40 & 50 \\
& Primary school & 15 & 2.5 & 8.75 \\
& Junior high school & 12.5 & 7.5 & 10 \\
& Senior high school & 50 & 37.5 & 43.75 \\
Subject occupation & Graduate & 22.5 & 52.5 & 37.5 \\
& Farmer & 5 & 0 & 2,5 \\
& Government staff & 5 & 15 & 10 \\
& Private employees & 25 & 35 & 30 \\
Had a miscarriage & Entrepreneur & 30 & 20 & 25 \\
Antenatal care & Housewife & 35 & 17.5 & 32.5 \\
& Ever & 80 & 82.5 & 48.75 \\
& Never & 20 & 62.5 & 51.25 \\
& Doctor & 72.5 & 25 & 67.5 \\
& Midwife & 15 & 5 & 20 \\
& Primary health care & 12.5 & 7.5 & 3.75 \\
\hline
\end{tabular}

Table 3. Behaviors and Habits at Risk of Toxoplasma Infection in Maternal Case and Control Groups

\begin{tabular}{|c|c|c|c|c|c|c|}
\hline Risk Factor for Toxoplasmosis & Category & $\mathbf{n}$ & $\%$ & $\mathbf{n}$ & $\%$ & p-value \\
\hline \multirow[t]{2}{*}{ Contact with ground } & Yes & 25 & 62.50 & 17 & 42.50 & \multirow[t]{2}{*}{0.073} \\
\hline & No & 15 & 37.50 & 23 & 57.50 & \\
\hline Water sources & Non-tap water & 18 & 45 & 23 & 57.50 & 0.263 \\
\hline The habit of washing food ingredients & No & 2 & 5 & 1 & 2.50 & 0.556 \\
\hline \multirow[t]{2}{*}{ Drinking water } & Boiled & 35 & 87.50 & 37 & 92.50 & \multirow[t]{2}{*}{0.456} \\
\hline & Not boiled & 5 & 12.50 & 3 & 7.50 & \\
\hline \multirow[t]{2}{*}{ Daily food } & Self-cook & 36 & 90 & 35 & 87.50 & \multirow[t]{2}{*}{0.724} \\
\hline & Do not self-cook & 4 & 10 & 5 & 12.50 & \\
\hline
\end{tabular}


Table 4. The Presence of Cats in or around the House and Its Relation with the Incidence of Toxoplasmosis in Maternal Mothers

\begin{tabular}{|c|c|c|c|c|c|c|}
\hline The Presence of Cat & Category & $\mathbf{n}$ & $\%$ & $\mathbf{n}$ & $\%$ & p-value \\
\hline \multirow[t]{2}{*}{ Cat maintenance } & Maintain & 8 & 20 & 4 & 10 & 0.21 \\
\hline & Not keeping (feral) & 32 & 80 & 36 & 90 & \\
\hline The gender of cats & Male & 19 & 47.5 & 16 & 40 & 0.499 \\
\hline The age of cats & $0-1$ year & 30 & 75 & 29 & 72.5 & \\
\hline \multirow[t]{2}{*}{ Handling of cat feces } & Cleaned & 11 & 27.5 & 12 & 30 & 0.81 \\
\hline & Not cleaned & 29 & 72.5 & 28 & 70 & \\
\hline \multirow[t]{2}{*}{ Examination of cat feces } & Positive & 12 & 30 & 2 & 5 & $0.003 *$ \\
\hline & Negative & 28 & 70 & 38 & 95 & \\
\hline
\end{tabular}

Table 5. Independent Variables Affecting the Incidence of Toxoplasmosis in Maternal Mothers and the Final Model of Logistic Regression

\begin{tabular}{lrrr}
\hline Variable & OR & p-value & 95\% CI \\
\hline Maternal education level & 0.503 & 0.029 & $0.272-0.932$ \\
Cats positive with toxoplasmosis by serological test & 5.542 & 0.003 & $1.816-16.916$ \\
Positive cat feces contained T. gondii oocysts by microscopic test & 14.153 & 0.003 & $2.523-79.394$
\end{tabular}

Notes: $\mathrm{OR}=$ Odds Ratio, $\mathrm{CI}=$ Confidence Interval, GOF = Goodness of Fit Test

like bathing, washing, cooking, and others was obtained from the regional drinking water company (tap), wells, rivers, and springs. The four sources were grouped into two, namely, tap and non-tap sources. As much as $51.25 \%$ of the water used by the respondents was from non-tap (wells, rivers, springs) sources, and the remaining $48.75 \%$ was from the tap. Toxoplasma sp. infection is avoidable when the food or water consumed is free of $T$. gondii oocyst contamination. This is achievable with the habit of washing meat, vegetables, or other foodstuffs before cooking or eating them. Among the maternal women interviewed, $96.25 \%$ stated that they always wash meat, vegetables, or other food ingredients before cooking or consumption, while the remaining 3.75\% have the habit of not washing them.

Table 4 shows the presence of cats in or around the house of maternal women. The presence of cats at home or around the house of the subjects in the case group indicated that $80 \%$ were feral or not kept, and it was observed to be $90 \%$ in the control group. The statistical analysis showed no significant relationship between raising cats and the incidence of toxoplasmosis in maternal women ( $p$-value $=0.499>\alpha=0.05)$. Most of the cats residing in and around their houses were under one year old, which was $75 \%$ in the case group and $72.5 \%$ in the control group. Statistically, the relationship between cat age and the incidence of toxoplasmosis in maternal women was not significant ( $p$-value $=0.799>\alpha=0.05$ ).
In this study, information on handling cat feces in or around the house was also extracted; as many as $72.5 \%$ of them from the case group stated that they did not usually clean the feces. Also, 70\% of maternal women from the control group stated the same behavior. The results of this study statistically did not show a significant relationship between handling cat feces and the incidence of toxoplasmosis $(p$-value $=0.81>\alpha=0.05$ ).

Table 5 shows the independent variables that affected the incidence of toxoplasmosis in maternal women and is the final logistic regression model. The results indicated that the level of maternal education, the presence of toxoplasmosis-positive cats evaluated by serological tests, and their feces by coproscopy, which contained $T$. gondii oocysts that contaminated the environment were risk factors for the incidence of toxoplasmosis in maternal women in Bali Province.

\section{Discussion}

This study revealed that a difference exists between the subjects' groups based on the age of maternal women. Several studies on the relationship between age and the incidence of toxoplasmosis have been reported with various results. In Thailand, it has been reported that the highest prevalence of toxoplasmosis in pregnant women was between 20-40 years of age. ${ }^{35}$ Another study conducted in Korea and China by Rai, et al., discovered that the highest prevalence occurred in the age group over 40 
years. ${ }^{36}$ Recent report in the Wasit Province of Iraq gave the highest infection rate as $19.9 \%$ in women aged 20 29 years, but with no significant difference between the ages studied. ${ }^{37}$ The results of this study and two others in Asia showed that the incidence of toxoplasmosis in pregnant women was not influenced by age. ${ }^{35,42}$ This agreed with Fromont, et al., 38 which stated that individuals are at risk of contracting toxoplasmosis throughout their lifetime. According to these findings, each age group had a high risk of toxoplasmosis infection. Therefore, early detection, prevention, and treatment programs should target all age groups.

The statistical test results in the education level variable revealed that the value of $\mathrm{OR}=3.4$, which means that maternal women who attended only elementary and junior high schools were at risk of contracting toxoplasmosis. This was about 3.4 times greater than those with sufficient education (senior high school and college graduates). The results of this study were in line with that conducted by Ferreira, et al., ${ }^{39}$ in which a low level of education greatly influenced the incidence of toxoplasmosis in residents of a Brazilian Amazonian village. According to the study of Lopes, et al., ${ }^{40}$ a relationship exists between education level and economic status on the incidence of toxoplasmosis in pregnant women in Parana, Brazil. However, this result is in contrast to that obtained from the study by Kapperud, et al.,${ }^{41}$ which reported that the level of education did not significantly influence $(\mathrm{OR}=1.8$, $\mathrm{p}$-value $=0.08)$ the incidence of toxoplasmosis in pregnant women in Norway. This may be influenced by many factors, including climate, the population density of cats-especially the feral ones, sociocultural status, level of education, knowledge, and healthy living behaviors. ${ }^{42,43}$ Since a low educational level contributes to an increased likelihood of being infected by toxoplasmosis, health promotion programs must aim at targeting those who have low educational levels. Their low educational levels notwithstanding, adequate knowledge related to risk and prevention behavior of toxoplasmosis transmission could reduce the risk of toxoplasmosis infections.

Miscarriage is one of the symptoms of $T$. gondii infection in pregnant women, ${ }^{44-46}$ therefore, the history of this occurrence was also analyzed in this study. Generally, the results obtained indicated that $48.75 \%$ of all the participating maternal women had experienced miscarriages. In the group of those infected with $T$. gondii (cases), $80 \%$ had a positive history of a miscarriage, while in the uninfected group (control), $10.75 \%$ had such experience. This data statistically shows a very significant difference $(\mathrm{p}$-value $=0.003)$ with an OR of 18.8 , which means that those infected with $T$. gondii have nearly 19 times the risk of miscarriage compared to the uninfected ones. This study's results were much higher than those obtained from a study conducted in Sudan by Mohamed, et al., ${ }^{47}$ who discovered that pregnant women who contracted toxoplasmosis had a three times greater risk of experiencing miscarriage than those who were not infected. Another study by Khurana, et al., ${ }^{48}$ in Sri Lanka reported that miscarriage in pregnant women was caused by $T$. gondii infection. Ekanayake and Kurukulasuriya reported that $34 \%$ to $58.5 \%$ of pregnant women in Sri Lanka that were infected experienced spontaneous abortion. ${ }^{49}$ Since miscarriage occurred due to toxoplasmosis infection; health programs should promote the early detection in women, especially prior to conception. A detection conducted in late pregnancy could increase the likelihood of a miscarriage and maternal problems. Therefore, toxoplasmosis screening among all women of reproductive age is an essential priority in health programs.

The habit of washing meat and vegetables before they are processed has a significant role in preventing toxoplasmosis in humans, especially when consuming raw items. ${ }^{50,51}$ The results obtained in this study indicated that $3.75 \%$ of the respondents were still in the habit of not washing before cooking. Kapperud, et al., ${ }^{41}$ agree that consuming raw vegetables and fruits that are dirty (not washed) causes a higher contraction rate of toxoplasmosis infection. Various studies on habit or lifestyle have been reported as risk factors for $T$. gondii infection in humans, but the reports vary by region or country. $20,42,43,52$ This is due to the different modes of transmission of the disease, as most toxoplasmosis occurrences in urban areas in Brazil occur due to ingestion of oocysts that contaminate drinking water or vegetables. ${ }^{28,29}$ Similar observations have been reported in several other developing countries such as Turkey, 30 Armenia, and Colombia. ${ }^{53}$ In contrast, the mode of transmission of toxoplasmosis in humans in developed countries such as in Europe is mostly by consuming meat or processed products that have not been cooked completely. ${ }^{27}$ Based on these findings, it is essential to promote hygienic behavior among members of the society regardless of their location in urban or rural areas, by publicizing prevention messages, especially those relating to food processing and storage, and making adequate clean water accessible along with prioritizing the provision of better sanitation facilities in the society.

As many as $85 \%$ of the respondents have both domestic and feral cats around their houses. Cat gender was balanced between the groups: $56.25 \%$ female and $43.75 \%$ male, and most of them were feral or not adequately maintained. These conditions are expected to continuously increase the population of stray cats in Bali Province, a medium for spreading toxoplasmosis. ${ }^{16}$ Judging from the cats' ages, $73.75 \%$ of them were less than one year old and, when infected with $T$. gondii, there 
is a likelihood of a broader and faster spread in Bali Province. In addition, cats under one year of age do not have antibodies against the parasite. Thus, they are easily infected. Tenter, et al.,54 stated that cats less than oneyear-old produce $T$. gondii oocysts in greater numbers than adult cats. Kapperud, et al., ${ }^{41}$ supports this observation by finding that pregnant women who have daily contact with kittens aged less than one year old are four times more likely to contract toxoplasmosis than those who do not. The existence of cats among humans is inevitable, so it is essential to prevent contamination from cat feces by controlling the population of cats. In collaboration with the local authority, communities could sterilize the cats to reduce their population. Promoting healthy pet ownership could also be an empowering approach by communities to prevent the spread of toxoplasmosis infections.

This study provided an in-depth understanding of the risk factors of toxoplasmosis infection among maternal women in Bali Province. It is noteworthy that the issue of toxoplasmosis has not been well explored in Bali Province. Therefore, this study provided recent updates relating to the status of zoonosis in Bali Province, which has hitherto been neglected but can potentially cause serious public health impacts. Although this study better comprehends the seroprevalence and risk factors of toxoplasmosis among maternal women, it can still not depict the situation in other parts of Bali Province. Furthermore, this study's sample size was small; thus, it is essential to conduct further study targeting a broader population, such as women of reproductive age from other parts of Bali Province.

\section{Conclusion}

The proportion of oocysts and the seroprevalence of T. gondii in cats was $17.5 \%$ and $47.5 \%$, respectively. A low education level and the presence of toxoplasmosis in cat feces determined by both serological and microscopic tests increase the risk of toxoplasmosis infection among pregnant women in Bali Province. In response to these findings, health prevention programs should target individuals with low educational levels and promote cleanliness and hygienic behavior. Moreover, encouraging women of reproductive age to participate in toxoplasmosis screening programs is also essential, especially to prevent the risk of miscarriage and the maternal health problems that may occur. In addition, controlling the cat population and providing better sanitation access is essential to prevent the transmission of toxoplasmosis.

\footnotetext{
Abbreviations

T. gondii: Toxoplasma gondii; ELISA test: Enzyme-Linked Immunosorbent Assay; IgG: Gamma Immunoglobulin; CI: Confidence Interval; OR: Odds Ratio; GOF: Goodness Of Fit Test.
}

\section{Ethics Approval and Consent to Participate}

Ethics approval was obtained from Griffith University Human Research Ethics Committee (GU ref no: 2019/424) and the Universitas Airlangga (ref no: 15494-KEPK). All participants gave informed written consent.

\section{Competing Interest}

The author declares that there are no significant competing financial, professional, or personal interests that might have affected the performance or presentation of the work described in this manuscript.

\section{Availability of Data and Materials}

The authors confirm that the data supporting the findings of this study are available within the article and its supplementary materials.

\section{Authors' Contribution}

MS conceived the idea, sampling design, data collection, and analyzed and interpreted the study results. MS, NPAH, KKA performed the data collection, critically analyzed and interpreted the study results, drafted the manuscript, and submitted it. NMA, NTS, MD gave their expert opinion in the sampling design and critically analyzed the data for important intellectual content. KKA and SGP gave her input in the manuscript drafting.

\section{Acknowledgment}

The authors would like to express the gratitude to the Rector of Udayana University for the funding and support to this study.

\section{References}

1. Flegr J, Prandota J, Sovičková M, Israili ZH. Toxoplasmosis-a global threat. Correlation of latent toxoplasmosis with specific disease burden in a set of 88 countries. PLoS One. 2014; 9 (3): 1-22.

2. El-Bissati K, Levigne P, Lykins J, Adlaoui EB, Barkat A, Berraho A, et al. Global initiative for congenital toxoplasmosis: an observational and international comparative clinical analysis. Emerging Microbes \& Infections. 2018; 7 (1): 1-14.

3. Aguirre AA, Longcore T, Barbieri M, Dabritz H, Hill D, Klein PN, et al. The one health approach to toxoplasmosis: epidemiology, control, and prevention strategies. Ecohealth. 2019; 16 (2): 378-90.

4. Molan A, Nosaka K, Hunter M, Wang W. Global status of Toxoplasma gondii infection: systematic review and prevalence snapshots. Tropical Biomedicine. 2019; 36 (4): 898-925.

5. Luc Paris. Toxoplasmosis. Hunter's Tropical Medicine and Emerging Infectious Disease. 2020; 10 (106): 803-13.

6. Chomel BB, Kasten R, Adams C, Lambillotte D, Theis J, Goldsmith R, et al. Serosurvey of some major zoonotic infections in children and teenagers in Bali, Indonesia. Southeast Asian Journal of Tropical Medicine and Public Health. 1993; 24 (2): 321-6.

7. Matsuo K. Investigation of toxoplasma gondii antibody in human in Bandar Lampung. Bulletin BPPH III Lampung. 1995; 11: 1-6.

8. Uga S, Ono K, Kataoka N, Hasan H. Seroepidemiology of five major zoonotic parasite infections in inhabitants of Sidoarjo, East Java, Indonesia. Southeast Asian Journal of Tropical Medicine and Public Health. 1996; 27: 556-61. 
9. Fan CK, Su KE, Wu GH, Chiou HY. Seroepidemiology of Toxoplasma gondii infection among two mountain Aboriginal populations and Southeast Asian laborers in Taiwan. Journal of Parasitology. 2002; 88 (2): 411-4.

10. Dwinata IM, Sutarga IM, Damriyasa IM. The potential risk factors for toxoplasmosis in Balinese pregnant women-Indonesia. Bali Medical Journal. 2016; 5 (1): 116-8.

11. Retmanasari A, Widartono BS, Wijayanti MA, Artama WT. Prevalence and risk factors for toxoplasmosis in Middle Java, Indonesia. Ecohealth. 2017; 14 (1): 162-70.

12. Tuda J, Adiani S, Ichikawa-Seki M, Umeda K, Nishikawa Y. Seroprevalence of Toxoplasma gondii in humans and pigs in North Sulawesi, Indonesia. Parasitology International. 2017; 66 (5): 615-8.

13. Sukaryawati P. Faktor risiko kejadian toksoplasmosis pada ibu hamil di wilayah Kecamatan Mengwi Kabupaten Badung tahun 2011. Program Studi Kesehatan Masyarakat Fakultas Kedokteran Universitas Udayana; 2011.

14. Laksemi DAAS, Artama W tunas, Wijayanti MA. Seroprevalensi yang tinggi dan faktor-faktor risiko toksoplasmosis pada darah donor dan wanita di Bali. Jurnal Veteriner. 2013; 14 (2): 204-12.

15. Eka Febianingsih NP, Indriani C, Artama WT. Seroprevalensi toksoplasmosis di Kabupaten Gianyar, Bali. Berita Kedokteran Masyarakat. 2017; 33 (2): 61.

16. Subrata IM, Suryadhi NT, Mantik-Astawa N, Damriyasa IM. Epidemiological and molecular analysis of Toxoplasma gondii in faecal samples of cats obtained from house of maternal in Bali. Bali Medical Journal. 2015; 4 (2): 68-75.

17. Wirata IW. Perbandingan predileksi sista Toxoplasma gondii pada jantung dan diafragma babi di Bali. Jurnal Sain Veteriner. 2014; 32 (2): $185-90$.

18. Dwinata IM, Oka IBM, Suratma NA, Damriyasa IM. Seroprevalensi dan isolasi Toxoplasma gondii pada ayam kampung di Bali. Veteriner. 2012; 13 (4): 340-4.

19. Liu Q, Wei F, Gao S, Jiang L, Lian H, Yuan B, et al. Toxoplasma gondii infection in pregnant women in China. Transactions of the Royal Society of Tropical Medicine and Hygiene. 2009; 103 (2): 1626.

20. Avelino MM, Campos D, Parada JB de, Castro AM de. Risk factors for Toxoplasma gondii infection in women of childbearing age. Brazilian Journal of Infectious Diseases. 2004; 8 (2): 164-74.

21. Ayi I, Edu S, Apea-kubi K., Boamah D, Bosompem K, Edoh D. Seroepidemiology of toxoplasmosis amongst pregnant women in the greater Accra region of Ghana. Ghana Medical Journal. 2010; 43 (3): 107-14.

22. Fonseca AL, Silva RA, Fux B, Madureira AP, de Sousa FF, Margonari C. Aspectos epidemiológicos da toxoplasmose e avaliação de sua soroprevalência em gestantes. Revista da Sociedade Brasileira de Medicina Tropical. 2012; 45 (3): 357-64.

23. VanWormer E, Fritz H, Shapiro K, Mazet JAK, Conrad PA. Molecules to modeling: Toxoplasma gondii oocysts at the human-animal-environment interface. Comparative Immunology, Microbiology \& Infectious Diseases. 2013; 36 (3): 217-31.

24. Dabritz HA, Conrad PA. Cats and toxoplasma: implications for public health. Zoonoses Public Health. 2010; 57 (1): 34-52.

25. Ayinmode AB, Obebe OO, Olayemi E. Prevalence of potentially zoonotic gastrointestinal parasites in canine faeces in Ibadan, Nigeria. Ghana Medical Journal. 2016; 50 (4): 201-6.

26. Stelzer S, Basso W, Benavides Silván J, Ortega-Mora LM, Maksimov $\mathrm{P}$, Gethmann J, et al. Toxoplasma gondii infection and toxoplasmosis in farm animals: risk factors and economic impact. Food and Waterborne Parasitology. 2019; 12 (2019): 1-32.

27. Dubey JP. Toxoplasmosis of animals and humans. Toxoplasmosis of Animals and Humans. 2010.

28. Bahia-Oliveira LMG, Jones JL, Azevedo-Silva J, Alves CCF, Oréfice F, Addiss DG. Highly endemic, waterborne toxoplasmosis in North Rio de Janeiro State, Brazil. Emerging Infectious Diseases. 2003; 9 (1): $55-62$.

29. Heukelbach J, Meyer-Cirkel V, Moura RCS, Gomide M, Queiroz JAN, Saweljew P, et al. Waterborne toxoplasmosis, Northeastern Brazil. Emerging Infectious Diseases. 2007; 13 (2): 287-9.

30. Ertug S, Okyay P, Turkmen M, Yuksel H. Seroprevalence and risk factors for toxoplasma infection among pregnant women in Aydin province, Turkey. BMC Public Health. 2005; 5 (66): 1-6.

31. Gandahusada S. Study on the prevalence of toxoplasmosis in Indonesia. A Review. Southeast Asian Journal of Tropical Medicine and Public Health. 1991; 22: 93-8.

32. Dwinata IM, Oka IBM, Agustina KK, Damriyasa IM. Seroprevalence of neospora caninum in local Bali dog. Veterinary World. 2018; 11 (7): 926-9.

33. Dahlan M. Besar sampel dan cara pengambilan sampel dalam penelitian kedokteran dan kesehatan. Jakarta: Penerbit Salemba Medika; 2009.

34. Castillo-Morales VJ, Acosta Viana KY, Guzmán-Marín EDS, JiménezCoello M, Segura-Correa JC, Aguilar-Caballero AJ, et al. Prevalence and risk factors of toxoplasma gondii infection in domestic cats from the tropics of mexico using serological and molecular tests.

Interdisciplinary Perspectives on Infectious Diseases. 2012; 2012 (529108): 1-6.

35. Nissapatorn V, Suwanrath C, Sawangjaroen N, Ling LY, Chandeying $\mathrm{V}$. Toxoplasmosis-serological evidence and associated risk factors among pregnant women in southern Thailand. American Journal of Tropical Medicine and Hygiene. 2011; 85 (2): 243.

36. Rai SK, Kubo T, Yano K, Shibata H, Sumi K, Matsuoka A, et al. Seroepidemiological study of toxoplasma infection in central and western regions in Nepal. Southeast Asian Journal of Tropical Medicine and Public Health. 1996; 27 (3): 548-53.

37. Al-Sray AH, Sarhan SR, Mohammed HA. Molecular and serological characterization of Toxoplasma gondii in women in Wasit Province. Advances in Animal and Veterinary Sciences. 2019; 7 (8): 657-63.

38. Fromont EG, Riche B, Rabilloud M. Toxoplasma seroprevalence in a rural population in France: detection of a household effect. BMC Infectious Diseases. 2009; 9 (76): 1-7.

39. Ferreira MU, Hiramoto RM, Aureliano DP, Da Silva-Nunes M, Da Silva NS, Malafronte RS, et al. A community-based survey of human toxoplasmosis in rural Amazonia: seroprevalence, seroconversion rate, and associated risk factors. American Journal of Tropical Medicine and Hygiene. 2009; 81 (1): 171-6.

40. Lopes FMR, Mitsuka-Breganó R, Gonçalves DD, Freire RL, Karigyo CJT, Wedy GF, et al. Factors associated with seropositivity for anti- 
toxoplasma gondii antibodies in pregnant women of Londrina, Paraná, Brazil. Memórias do Instituto Oswaldo Cruz. 2009; 104 (2): 378-82.

41. Kapperud G, Jenum PA, Stray-Pedersen B, Melby KK, Eskild A, Eng J. Risk factors for toxoplasma gondii infection in pregnancy: results of a prospective case-control study in Norway. American Journal of Epidemiology. 1996; 144 (4): 405-12.

42. Egorov AI, Converse R, Griffin SM, Styles J, Klein E, Sams E, et al. Environmental risk factors for Toxoplasma gondii infections and the impact of latent infections on allostatic load in residents of Central North Carolina. BMC Infectious Diseases. 2018; 18 (421): 1-11.

43. Smit GSA, Vu BTL, Do DT, Do QH, Pham HQ, Speybroeck N, et al. Sero-epidemiological status and risk factors of toxoplasmosis in pregnant women in Northern Vietnam. BMC Infectious Diseases. 2019; 19 (329): 1-8.

44. Chaudhry SA, Gad N, Koren G. Toxoplasmosis and pregnancy. Canadian Family Physician. 2014; 60 (4): 334-6.

45. Fenta DA. Seroprevalence of Toxoplasma gondii among pregnant women attending antenatal clinics at Hawassa University comprehensive specialized and Yirgalem General Hospitals, in Southern Ethiopia. BMC Infectious Diseases. 2019; 19 (1): 1-9.

46. Nayeri T, Sarvi S, Moosazadeh M, Amouei A, Hosseininejad Z, Daryani A. The global seroprevalence of anti-Toxoplasma gondii antibodies in women who had spontaneous abortion: a systematic review and meta-analysis. PLoS Neglected Tropical Diseases. 2020; 14 (3): 127.
47. Mohamed K, Kodym P, Maly M, El-Rayah I. Environmental and food habitat risk factors associated with Toxoplasma gondii infection in rural women in Sudan. International Journal of Current Microbiology and Applied Sciences. 2014; 3 (2): 208-22.

48. Khurana S, Bagga R, Aggarwal A, Lyngdoh V, Shivapriya, Diddi K, et al. Serological screening for antenatal toxoplasma infection in India. Indian Journal of Medical Microbiology. 2010; 28 (2): 143-6.

49. Ekanayake S, Kurukulasuriya NT. Prevalence of antibodies to Toxoplasma gondii in pregnant women. Kandy Medical Journal. 1995; 4 (2): 36-40.

50. Tenter AM. Toxoplasma gondii in animals used for human consumption. Memórias do Instituto Oswaldo Cruz. 2009; 104 (2): 364-9.

51. Alizadeh AM, Jazaeri S, Shemshadi B, Hashempour-Baltork F, Sarlak Z, Pilevar Z, et al. A review on inactivation methods of Toxoplasma gondii in foods. Pathogens and Global Health. 2018; 112 (6): 306-19.

52. Dong H, Su R, Lu Y, Wang M, Liu J, Jian F, et al. Prevalence, risk factors, and genotypes of Toxoplasma gondii in food animals and humans (2000-2017) from China. Frontiers in Microbiology. 2018; 9 (2108): $1-10$.

53. López-Castillo CA, Díaz-Ramírez J, Gómez-Marín JE. Factores de riesgo en mujeres embarazadas, infectadas por Toxoplasma gondii en Armenia-Colombia. Revista de Salud Pública. 2005; 7 (2): 180-90.

54. Tenter AM, Heckeroth AR, Weiss LM. Toxoplasma gondii: from animals to humans. International Journal for Parasitology. 2000; 30 (1213): 1217-58. 